\title{
Menurun dan Meningkat, Maju Namun Belum Cukup: Kinerja Pembangunan Sektor Energi di Tengah Pandemi Covid-19 Tahun 2020
}

Hanan Nugroho ${ }^{1}$ dan Muhyiddin²

${ }^{1}$ Perencana Ahli Utama di Kedeputian bidang Kemaritiman dan Sumber Daya Alam, Kementerian PPN/Bappenas

${ }^{2}$ Perencana Ahli Madya di Pusat Analisis Kebijakan dan Kinerja, Kementerian $\mathrm{PPN} /$ Bappenas

Korespondensi: nugrohohn@bappenas.go.id

Doi: doi.org/10.47266/bwp.v4i1.95| halaman: 1-12

Dikirim: 28-03-2021 | Diterima: 29-03-2021 | Dipublikasikan: 31-03-2021

\begin{abstract}
Abstraksi
Di tengah pandemi Covid-19 dalam tahun 2020, kinerja pembangunan sektor energi bervariasi. Konsumsi energi, baik BBM, maupun listrik menurun terutama karena pembatasan kegiatan transportasi dan produksi industri (termasuk UMKM). Produksi energi primer seperti minyak bumi, gas bumi, dan batubara juga menurun atau di bawah target karena terganggunya sistem logistik dan rantai pasok. Investasi di sektor energi menurun, subsidi energi meningkat. Walaupun produksi dan konsumsi energi menurun, namun sumbangan energi kepada pendapatan negara tahun 2020 lebih besar daripada yang ditargetkan. Tahun 2020 menunjukkan perkembangan menggembirakan dalam peningkatan rasio elektrifikasi, sebaran program "BBM Satu Harga”, dan peningkatan jumlah rumah tangga yang tersambung aliran gas bumi. Pemanfaatan energi terbarukan dalam pembangkitan listrik dan bio-diesel meningkat, namun pangsa energi terbarukan dalam bauran energi nasional masih rendah untuk dapat mencapai target 23 persen pada tahun 2025.
\end{abstract}

Kata kunci: pembangunan sektor energi, pandemic covid-19 


\title{
Menurun dan Meningkat, Maju Namun Belum Cukup: Kinerja Pembangunan Sektor Energi di Tengah Pandemi Covid-19 Tahun 2020
}

\author{
Hanan Nugroho \& Muhyiddin
}

\section{Pendahuluan}

Pada awal tahun 2020 dunia dikejutkan oleh serangan pandemi virus dengan nama Covid-19 yang berawal dari Wuhan, China, dimana pandemi tersebut masih berlanjut sampai sekarang di seluruh dunia. Covid-19 berdampak besar pada ekonomi. Perekonomian global maupun domestik menyusut secara drastis. Dalam tahun 2020, ekonomi Indonesia mengalami kontraksi atau minus 2,07 persen dibandingkan tahun 2019 (BPS, 2021), atau jauh lebih rendah dibandingkan target pertumbuhan 5,6 persen - 6,2 persen yang dipatok dalam Rencana Pembangunan Jangka Menengah Nasional (RPJMN) 2020-2024. Perekonomian Indonesia mengalami hantaman cukup kuat pada kuartal kedua dan ketiga tahun 2020 dimana berturut-turut pertumbuhan ekonomi menurun hingga -5,3 persen dan $-3,5$ persen. Sementara di kuartal keempat 2020 angka pertumbuhan ada di -2,19 (Bappenas, 2021).

Banyak sektor ekonomi mengalami penurunan output, antara lain ditunjukkan oleh sektor transportasi, pariwisata, kegiatan UMKM (usaha mikro, kecil dan menengah), perhotelan, agen perjalanan, dan sektor-sektor lainnya. Namun di balik itu ternyata Covid19 membawa "berkah" bagi beberapa sektor: perdagangan secara elektronik (e-commerce), teknologi informasi \& komunikasi, jasa pengiriman/delivery, industri kesehatan, dll., serta tidak memberikan dampak yang besar terhadap sektor pertanian, misalnya.

Energi berperan sangat penting dalam ekonomi, sering disebut sebagai "mesin" kegiatan ekonomi. Bila energi tidak ada, kegiatan ekonomi tidak dapat berlangsung. Nilai perdagangan energi sangat besar, baik di dalam negeri maupun internasional untuk beberapa negara. Energi dalam bentuk BBM (bahan bakar minyak), gas bumi, atau listrik, dibutuhkan manusia dimana saja, untuk menggerakkan kegiatan (dan memberikan "kenyamanan"). Energi harus tersedia setiap saat, meskipun dengan jumlah, jenis dan kualitas yang berbedabeda.

Bagi suatu negara, kebutuhan terhadap energi bersifat primer, termasuk dalam situasi krisis seperti diakibatkan oleh Covid-19. Namun, sifat permintaan terhadap energi adalah "turunan" (derived demand), mengikuti perkembangan dari kegiatan-kegiatan (industri, transportasi, perkantoran, dsb.) dimana energi berperan untuk menggerakkannya.

Makalah ini melihat perkembangan yang terjadi dalam sektor energi di Indonesia, khususnya selama tahun 2020 dimana Covid-19 sedang melanda dan belum menunjukkan penurunan hingga makalah ini dibuat dalam kuarter pertama 2021.

\section{Kinerja Sektor Ekonomi}

Beberapa kinerja ekonomi sektor energi sepanjang 2020 dapat diringkaskan sebagai berikut: (1) Konsumsi menurun, namun sumbangan sektor energi meningkat, (2) Investasi di sektor energi lebih rendah daripada yang direncanakan, (3) Subsidi energi meningkat. 
Sebagaimana banyak diperkirakan, Covid-19 memberikan dampak penurunan konsumsi energi, baik untuk BBM, gas bumi, batubara, maupun listrik (Nugroho, 2020). Penyebabnya dapat dijelaskan dengan mudah. Perkantoran menerapkan kebijakan "Kerja dari Rumah", berbagai industri membatasi aktivitas karena permintaan akan produknya menurun, kegiatan ekonomi yang merosot dan kebijakan penanggulangan Covid-19 yang makin ketat berakibat perjalanan ke tempat kerja, sekolah/kampus maupun tempat-tempat lain berkurang banyak.

Penurunan kegiatan transportasi berpengaruh besar pada permintaan BBM (bahan bakar minyak). Kebijakan “jaga jarak” serta keharusan menyertakan hasil uji bebas Covid19 yang mahal berakibat jumlah penumpang dan frekuensi penerbangan turun drastis, menurunkan volume avtur maupun avgas yang dikonsumsi. Penurunan konsumsi minyak diesel dan gasoline yang menjadi bahan bakar utama bagi kendaraan-kendaraan di darat (sepeda motor, mobil penumpang) terjadi menyusul sejak keberadaan Covid-19 diumumkan pemerintah, namun telah naik kembali mulai kuarter terakhir tahun 2020.

Widyastuti dan Nugroho (2020) memberikan ilustrasi tentang kedalaman penurunan pada APBN 2020 dimana harga minyak mentah diasumsikan US $\$ 63$ per barel. Kenyataannya, Indonesian Crude Price (ICP) telah jatuh jauh di bawah angka asumsi APBN. Mengacu Tim Harga Minyak Indonesia, harga ICP Maret 2020 turun drastis hingga mencapai 40 persen menjadi US $\$ 34,23 /$ barel, atau merosot US $\$ 22,38 /$ barel dibandingkan bulan sebelumnya US\$ 56,61/barel. Jelas bahwa penurunan volume produksi serta penurunan harga minyak akan berbayang-bayang suram pada sisi penerimaan migas dalam APBN 2020 dan 2021.

Tidak diturunkannya harga penjualan BBM tentu saja tidak langsung berarti "kenaikan pendapatan" bagi perusahaan penjual BBM (dalam kasus Indonesia adalah Pertamina sebagai pemain utama), karena pada saat yang sama juga terjadi penurunan volume penjualan yang cukup besar, dan di samping itu perusahaan juga tetap harus memelihara asset (termasuk tenaga kerja) dari kegiatan-kegiatan di sisi hulu dan refining yang produktivitasnya merosot. Namun, untuk menjawab tuntutan sebagian masyarakat yang menginginkan penurunan harga BBM, soal transparansi mengenai pendapatan maupun biaya-biaya yang terjadi pada BUMN minyak negara sebagai dampak dari pandemi Covid19 perlu dikedepankan kepada masyarakat luas.

Penurunan konsumsi listrik terjadi di perkantoran, pusat-pusat perbelanjaan dan sebagian industri. Untuk kalangan rumah tangga, penurunan tersebut tidak besar, bahkan di sebagian rumah tangga (terutama di perkotaan) konsumsi listrik meningkat karena banyak kegiatan dilakukan di rumah. Sebagai tanggapan atas melemahnya kemampuan ekonomi masyarakat karena dampak Covid-19, pemerintah melakukan penghapusan dan penurunan tarif listrik untuk pelanggan rumah tangga kecil.

Harga minyak mentah (crude oil) di pasaran dunia sudah mulai turun sejak awal tahun 2020, terus jatuh hingga titik terendah (selama 17 terakhir) pada Mei 2020, kemudian merangkak naik hingga akhir tahun namun belum mencapai level harga pada awal tahun 
2020. Dalam kurun 2020, tercatat harga minyak mentah WTI tertinggi, terendah, dan ratarata adalah US\$ 63,27/barel, USS $\$ 11,26 /$ barel, dan US\$ 39,68/barel. ${ }^{1}$

Walaupun harga minyak anjlok dan konsumsi BBM menurun, namun sektor energi dan pertambangan Indonesia dalam tahun 2020 menyumbangkan pendapatan 20 persen lebih besar dibandingkan dari yang diproyeksikan semula, yaitu sebesar Rp. 108,8 Trilyun dibandingkan Rp. 90,7 Trilyun (Kementerian Energi dan Sumber Daya Mineral, 2021). Hal ini dapat dicapai antara lain karena walaupun harga minyak mentah dunia sedang jatuh, pemerintah tidak menurunkan harga jual BBM mengikuti merosotnya harga minyak mentah.

Walaupun sumbangan pendapatan sektor energi dan pertambangan di tengah krisis ekonomi 2020 cukup menggembirakan, namun sumbangan tersebut lebih rendah dibandingkan dengan 3 tahun berturut-turut sebelumnya ketika harga minyak lebih tingggi, konsumsi BBM dan listrik lebih tinggi, dan kegiatan lainnya di bidang energi seperti produksi dan perdagangan batubara memberikan sumbangan pendapatan lebih besar.

Investasi di sektor energi dalam tahun 2020 menurun dibandingkan tahun-tahun sebelumnya. Hal ini bisa dijelaskan karena Covid-19 mengganggu mobilitas, logistik dan suppply chain proyek-proyek energi baik di pertambangan hingga sisi penggunaan batubara, sejumlah proyek pembangunan infrastruktur energi seperti pembanggunan PLTU dibatalkan, kegiatan kilang minyak ada yang ditutup karena konsumsi BBM yang rendah, dsb. Dalam tahun 2020, investasi sektor energi dan pertambangan turun sebesar 26,5 persen dibandingkan investasi tersebut tahun sebelumnya. Investasi yang paling banyak mengalami penurunan adalah untuk pembangunan infrastruktur ketenagalistrikan, diikuti dengan untuk kegiatan-kegiatan di industri batubara dan mineral lainnya (Kementerian ESDM, 2021).

Sejak 2015 pemerintah Indonesia telah cukup berhasil dalam upaya menurunkan besaran "Subsidi Energi." Keberhasilan upaya tersebut terus berlanjut selama RPJMN 20152019. Kebijakan pengurangan subsidi BBM cukup berhasil, antara lain karena harga minyak mentah dunia mengalami penurunan, dan pemerintah Indonesia dengan Presiden baru Joko Widodo memutuskan untuk tidak menurunkan harga jual BBM di Tanah Air. Di sisi lain, penghematan yang diperoleh dari pengurangan subsidi BBM digunakan untuk memperluas jaringan distribusi BBM ke tempat-tempat yang terpencil dan sulit dijangkau, yang sebelumnya mendapatkan BBM dengan harga sangat mahal.

${ }^{1}$ https://www.macrotrends.net/2516/wti-crude-oil-prices-10-year-daily-chart 


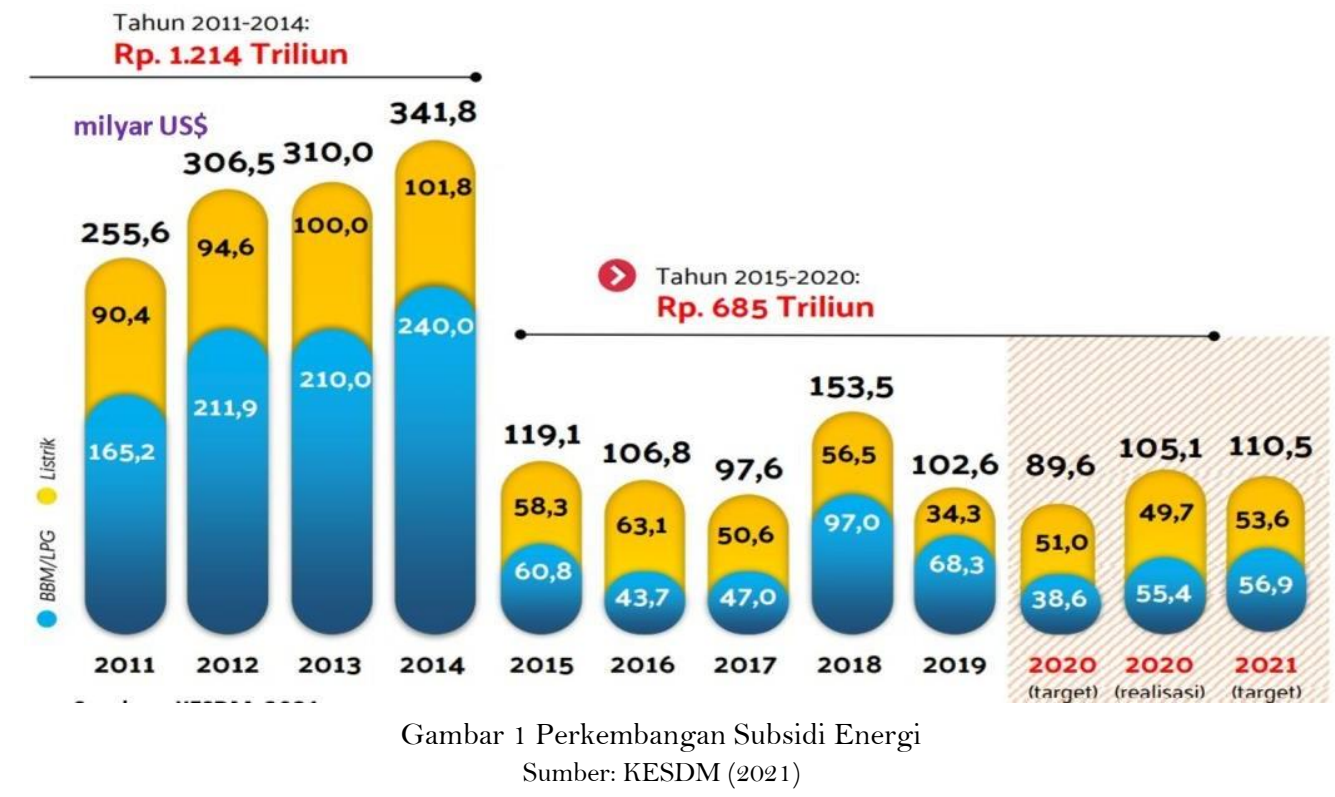

Sebagai tampak dalam Gambar 1, dalam RPJMN 2015-2019 terdapat peralihan jumlah yang cukup besar dari "Subsidi BBM" (termasuk LPG) ke "Subsidi Listrik" Dalam kurun panjang "Subsidi BBM" menjadi permasalahan yang dihadapi pemerintah Indonesia dengan jenis-jenis BBM yang disubsidi bervariasi dari minyak tanah (kerosene), bensin dan solar, hingga LPG (liquefied petroleum gas). Sejak konsumsi listrik meningkat sebagai akibat percepatan pembangunan infrastruktur kelistrikan, dalam periode RPJMN 2015-2019 besaran "Subsidi Listrik" telah sering melewati besaran "Subsidi BBM". Dalam tahun 2020 besaran "Subsidi Listrik" meningkat karena pemerintah menerapkan kebijakan penghapusan/pengurangan subsidi listrik sebagaimana telah dikemukakan sebelumnya. Subsidi BBM juga meningkat, ditujukan terutama untuk membiayai pemakaian LPG yang terus tumbuh di Tanah Air.

Bappenas (2021b) dalam Laporan Perkembangan Ekonomi Indonesia dan Dunia menyebutkan bahwa pada triwulan IV tahun 2020, neraca perdagangan migas defisit sebesar USD1,3 miliar, lebih besar daripada defisit pada triwulan III tahun 2020 yang sebesar USD 1, 1 miliar. Hal tersebut disebabkan oleh impor migas Indonesia pada triwulan IV tahun 2020 yang sebesar USD3,6 miliar jauh lebih besar daripada total ekspor migas (USD2,4 miliar). Ekspor migas Indonesia tahun 2020 terkontraksi sebesar 20,9 persen dari tahun sebelumnya. Sementara itu, impor migas terkontraksi 39,5 persen dari impor tahun 2019.

Tabel 1. Nilai Ekspor dan Impor Migas

\begin{tabular}{|c|c|c|c|c|}
\hline \multirow{2}{*}{ Uraian } & \multirow{2}{*}{$\begin{array}{c}\text { Nilai Q4 } 2020 \\
\text { (juta USD) }\end{array}$} & \multicolumn{2}{|c|}{ Growth (\%) } & \multirow[t]{2}{*}{$\begin{array}{c}\text { Share thd Total* } \\
(\%)\end{array}$} \\
\hline & & QtQ & YoY & \\
\hline Ekspor Migas & $2.394,4$ & 23,0 & $-20,9$ & 5,2 \\
\hline $\begin{array}{l}\text { Minyak } \\
\text { Mentah }\end{array}$ & 728,1 & 85,1 & 59,2 & 1,6 \\
\hline Hasil Minyak & 296,8 & $-27,9$ & $-41,9$ & 0,6 \\
\hline
\end{tabular}




\begin{tabular}{lrrrr} 
Gas & $1.369,5$ & 20,0 & $-33,5$ & 3,0 \\
\hline Impor Migas & $3.645,6$ & 18,3 & $-39,5$ & 9,6 \\
\hline Minyak & 673,1 & $-8,83$ & $-60,9$ & 1,8 \\
Mentah & & & & \\
Hasil Minyak & $2.279,1$ & 24,98 & $-37,7$ & 6,0 \\
Gas & 693,4 & 33,6 & 7,7 & 1,8 \\
\hline
\end{tabular}

* share terhadap total ekpor/impor

Sumber: Badan Pusat Statistik, diolah

Ekspor dan impor migas pada kuartal 4 tahun 2020 meningkat masing-masing 23,0 dan 18,3 persen dibanding kuartal 3 tahun 2020. Kenaikan ekspor migas terutama didorong oleh ekspor gas yang tumbuh sebesar 20,9 persen (kuartal 4 terhadap kuartal 3 tahun 2020) dan minyak mentah yang mengalami kenaikan hingga 85,1 persen (kuartal 4 tahun 2020). Sementara itu, kenaikan impor migas lebih didorong oleh gas dan hasil minyak, masingmasing tumbuh 33,6 dan 25,0 persen (kuartal 4 tahun 2020).

\section{Produksi Menurun, Akses Energi Bertambah}

Produksi minyak bumi dan gas bumi dalam tahun 2020 masing-masing adalah 707 ribu barel per hari dan 975 ribu setara barel minyak per hari, atau totalnya 1.682 setara barel minyak per hari. Angka ini sedikit di bawah target produksi yang direncanakan.

Dalam kurun RPJMN 2015-2019 produksi minyak bumi Indonesia telah menurun dengan curam, dan hal ini sebetulnya mengikuti kecenderungan sebelumnya ketika Indonesia mengalami produksi puncak minyak bumi 1,7 juta barel per hari pada tahun 1977 . Dalam kurun RPJMN 2015-2019 pun produksi gas bumi terus menurun, berlanjut pada tahun 2020.

- Minyak Bumi (mbopd)

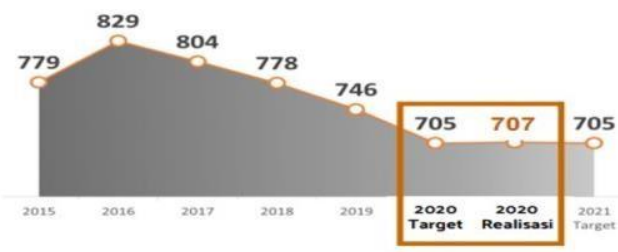

\section{- Gas Bumi (mboepd)}

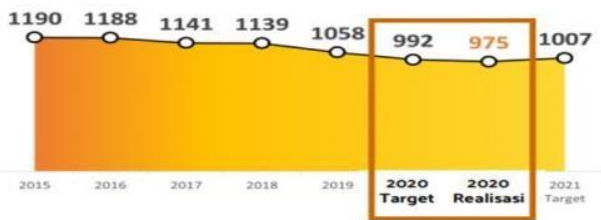

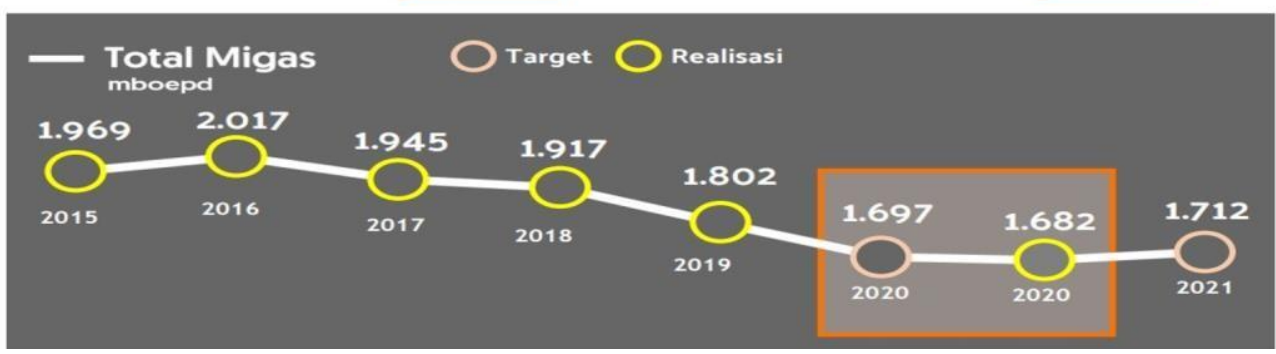

Gambar 2 Perkembangan Produksi Minyak dan Gas Bumi (ribu barel per hari) Sumber: KESDM (2021)

Penurunan kapasitas produksi minyak bumi serta gas bumi Indonesia merupakan permasalahan yang fundamental dan tidak bisa diselesaikan dalam jangka pendek atau ad hoc. Harus serius melakukan upaya mengatasi hal ini mulai dari peningkatan kegiatan 
eksplorasi, perbaikan teknik produksi, penyempurnaan regulasi dan sistem insentif, hingga penggalangan investasi. Bukan pekerjaan yang mudah, namun tanpa upaya ini Indonesia akan mengalami kesulitan yang lebih besar ke depan. Secara sumberdaya (resources) Indonesia masih memiliki potensi cadangan minyak dan gas bumi yang belum dieskplorasi.

Konsumsi BBM Indonesia masih akan terus naik, sementara kemampuan produksi telah jauh menurun. Peningkatan impor minyak mentah dan BBM selain memberatkan neraca pembayaran luar negeri juga akan meningkatkan "Subsidi BBM" yang menambah beban bagi APBN. Hal ini berlaku dalam situasi dimana harga BBM masih ditetapkan oleh pemerintah, dengan nilai yang sering di bawah harga keekonomiannya.

Produksi batubara dalam tahun 2020 mengalami penurunan dibandingkan produksinya pada tahun 2019. Namun demikian, realisasi produksi ini adalah lebih besar dibandingkan dengan yang diproyeksikan dalam RPJMN 2020-2024.

Sebagai ditunjukkan dalam Gambar 3, produksi batubara Indonesia tetap jauh lebih banyak yang diekspor (ke Cina, India, Jepang, dll.) meskipun pemakaian di dalam negeri juga terus meningkat, sebagian besar digunakan untuk bahan bakar PLTU yang dibangun di hampir seluruh wilayah Indonesia.

- Produksi Batubara Dalam Negeri

Realisasi 558 juta ton atau $101,4 \%$

lebih dari target 550 juta ton

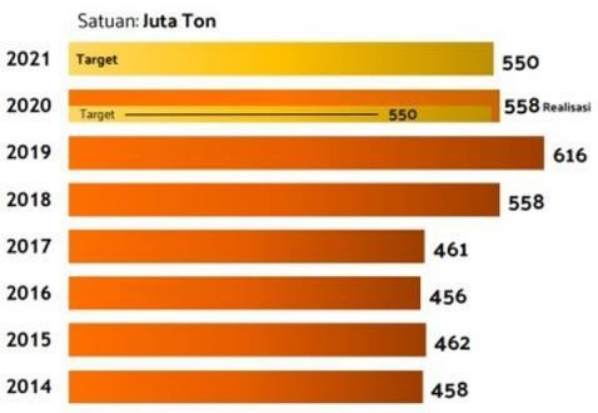

\section{- Pemanfaatan Batubara Domestik \\ Realisasi 132 juta ton atau $85 \%$ dari target 155 juta ton}

Satuan: Juta Ton

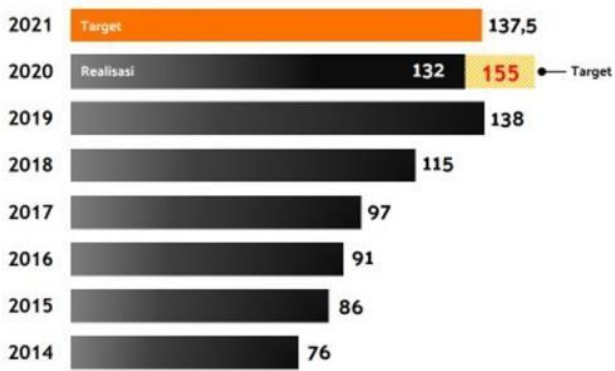

Gambar 3. Produksi dan pemanfaatan batubara di dalam negeri Sumber: KESDM (2021)

Pembangkitan tenaga listrik di Indonesia sekarang sangat didominasi oleh PLTU Batubara, terutama di Jawa dimana pembangkit-pembangkit berkapasitas besar berada (PLTU Suralaya di Banten, PLTU Tanjung Jati di Jawa Tengah, PLTU Paiton di Jawa Timur, dll.). Kebijakan Energi Nasional Indonesia (KEN, PP 79/2014) tidak bermaksud meniadakan penggunaan batubara, namun volumenya perlu dikendalikan dan tidak lagi dominan dalam bauran energi Indonesia di masa depan (2050). Karena itu, pemanfaatan batubara di dalam negeri hanya boleh tumbuh rendah, diturunkan produksinya dan bahkan dihentikan ekspornya sesuai skenario yang ditetapkan dalam Peraturan Presiden 22/2017 mengenai Rencana Umum Energi Nasional (RUEN).

Terlepas dari produksi sumber daya alam primer berupa minyak bumi, gas bumi, dan batubara yang turun, akses terhadap energi atau pelayanan energi kepada masyarakat terus meningkat. Ini adalah hal yang menggembirakan. 
Rasio elekrifikasi Indonesia pada akhir 2020 telah mencapai 99,2 persen, dengan hanya 3 propinsi yang rasio elektrofikasinya masih berada di bawah 90 persen. Propinsi Nusa Tenggara Timur memiliki rasio elektrifikasi terendah. Masih relatif rendahnya jangkauan pelayanan listrik ketiga propinsi tersebut dapat dijelaskan karena medan yang masih sulit dengan karakteristik kepulauan (Nusa Tenggara Timur dan Maluku) serta hutan yang lebat (Kalimantan Tengah). Namun demikian perluasan jangkauan pelayanan kelistrikan dapat terus dikembangkan di ketiga propinsi tersebut serta seluruh wilayah Nusantara dalam tahun-tahun mendatang, sehingga seluruh wilayah Indonesia terjangkau pelayanan listrik dengan jumlah dan mutu yang terus membaik. Gambar 4 memperlihatkan distribusi rasio elektrifikasi wilayah-wilayah Indonesia.

\section{Dalam 6 tahun terakhir rasio elektrifikasi meningkat 14,85\%, dari tahun 2014 sebesar $84,35 \%$ menjadi $99,20 \%$ tahun 2020}

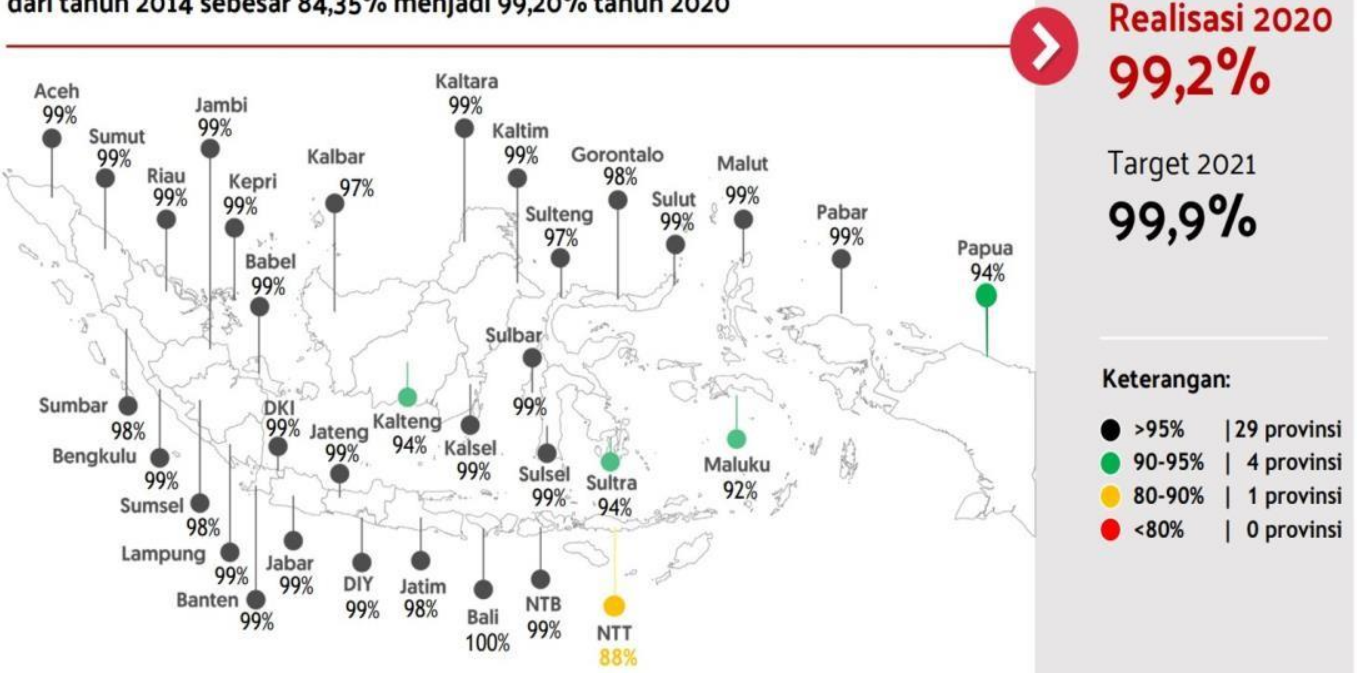

Gambar 4. Rasio elektrifikasi Indonesia tahun 2020

Sumber: KESDM (2021)

BBM yang sebelumnya sulit didapatkan atau berharga sangat mahal di beberapa pelosok Indonesia telah coba dijangkau oleh pemerintah dengan menetapkan sejumlah lokasi di daerah sulit dijangkau tersebut untuk menerapkan program "BBM Satu Harga" dimana BBM (bensin dan solar) dijual dengan harga yang sama dengan yang dijual di SPBU di Jawa, yaitu masing-masinng Rp. 6.450/liter dan Rp. 5.150/liter.

Pada tahun 2020, proggram “BBM Satu Harga” telah bertambah sebanyak 83 lokasi atau dengan penambahan yang lebih besar dibandingkan tahun-tahun sebelumnya semenjak program tersebut dimulai di era Presiden Joko Widodo. Hingga akhir tahun 2020, telah diselesaikan pembangunan fasilitas "BBM Satu Harga" di 253 lokasi, dengan yang terbanyak di Papua, Papua Barat, dan Maluku. Diharapkan pada akhir RPJMN 2020-2024 di seluruh Indonesia telah akan terbangun sejumlah 500 lokasi pelayanan "BBM Satu Harga", memudahkan rakyat di seluruh wilayah Indonesia mendapatkan BBM dengan harga dan mutu yang sama.

Gas bumi adalah suberdaya yang Indonesia memilikinya dalam jumlah besar, lebih besar dibandingkan untuk minyak bumi. Gas bumi adalah sumber energi yang bersih (lebih 
bersih dibandingkan minyak bumi dan batubara), pembakarannya efisien dan dapat dijual dengan harga lebih murah dibandingkan LPG (yang impornya telah meningkat pesat dalam tahun-tahun belakangan).

Upaya memanfaatkan kekayaan gas bumi sebagai sumber energi bersih dan modern untuk kebutuhan memasak (cooking) di rumah-rumah tangga di Tanah Air yang telah digencarkan dalam RPJMN 2015-2020 terus menunjukkan hasil yang positip pada tahun 2020. Sebagai ditunjukkan dalam Gambar 5, pada tahun 2020 dapat ditambah sejumlah 135.286 sambungan rumah (SR) gas bumi yang dipasang di 23 kabupatan dan kota di Indonesia, khususnya yang memiliki sumber gas atau dilintasi jaringan transmisi/distribusi gas bumi.

Dengan penambahan SR sebesar tersebut di atas, maka dalam tahun 2020 di Indonesia telah terdapat 673 ribu rumah tangga menggunakan gas bumi untuk memasak. Meskipun bertambah dengan cepat, jumlah ini kecil dibandingkan puluhan juta rumah tangga di Indonesia yang telah menggunakan LPG. Sebelumnya, digencarkan mulai tahun 2007 pemerintah Indonesia melakukan "langkah besar" dengan mengalihkan bahan bakar untuk memasak di rumah-rumah tangga dari minyak tanah (kerosene) ke LPG, membuat Indonesia termasuk yang berhasil di dunia untuk upaya peralihan ke bahan bakar bersih untuk memasak dalam skala jumlah rumah tangga yang besar (puluhan juta).

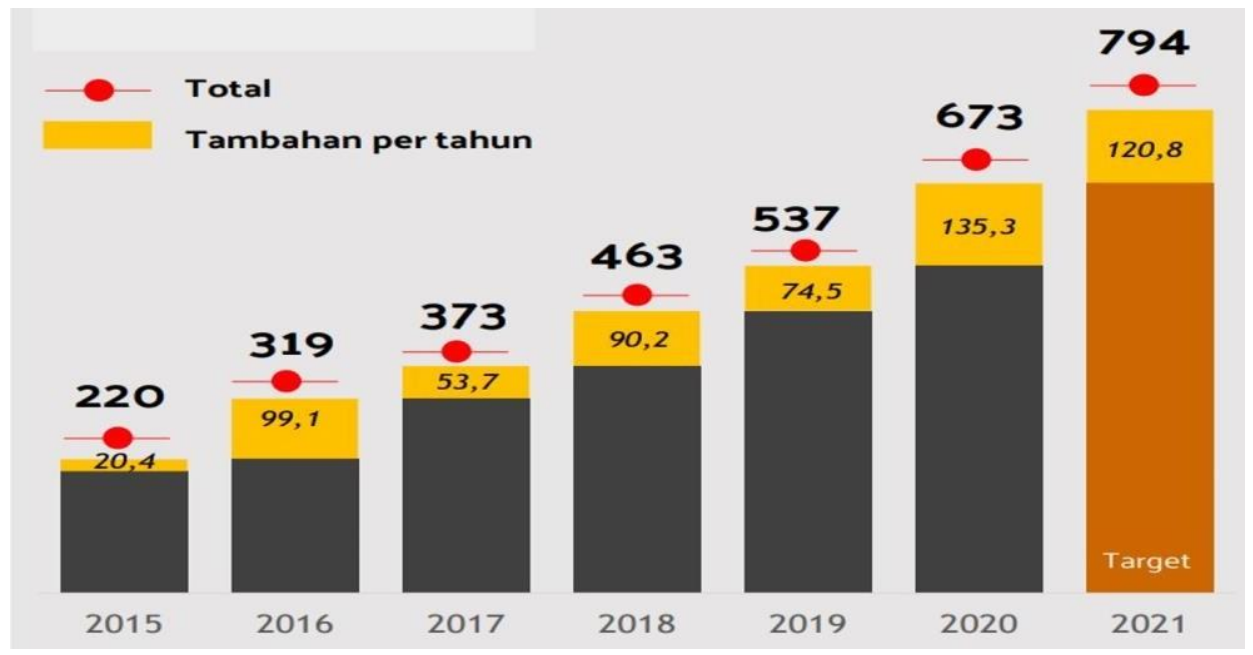

Gambar 5. Perkembangan jumlah Sambungan Rumah Gas Bumi di Indonesia (ribu SR) Sumber: KESDM (2021)

Mempertimbangkan nilai impor (dan subsidi) LPG yang terus meningkat, sangat penting untuk terus memperbesar jumlah SR gas bumi di Indonesia dengan memperluas jaringan transmisi dan distribusi gas bumi di Tanah Air.

Upaya lain penyediaan bahan bersih untuk memasak yang perlu dikembangkan adalah penggunaan kompor listrik induksi, dapat dimulai di daerah-daerah perkotaan. Harga kompor listrik telah semakin murah, sementara di beberapa wilayah di Indonesia, terutama di Jawa belakangan ini terjadi kelebihan pasokan pasokan listrik yang dapat digunakan untuk menyalakan kompor listrik di rumah-rumah tangga. 


\section{Penutup: Peningkatan Pangsa Energi Terbarukan: Jalan Masih Terjal}

Agenda besar Kebijakan Energi Nasional adalah meningkatkan pangsa energi terbarukan dalam bauran energi nasional hingga jauh ke depan. Hal ini ditegaskan dalam Peraturan Pemerintah No. 79 tahun 2014 mengenai “Kebijakan Energi Nasional." Sasaran yang ingin dituju adalah pangsa energi terbarukan dalam bauran energi nasional pada tahun 2025 telah menjadi minimal sebesar 23 persen, dan pada tahun 2050 minimal 31 persen. Indonesia sekarang masih sangat mengandalkan pemenuhan kebutuhan energinya dari bahan bakar fosil, baik untuk penggunaan langsung maupun untuk menjadi bahan bakar pembangkitan tenaga listrik.

Di Indonesia terdapat beraneka macam sumber energi terbarukan dalam jumlah besar dan tersebar di berbagai wilayah. Antara lain panas bumi, tenaga air, biomass, berbagai tumbuhan yang bisa dikembangkan menjadi bahan bakar nabati (BBN), tenaga surya, tenaga angin, energi laut, dan sebagainya. Dibandingkan potensinya dan yang telah dikembangkan di negara-negara tetangga seperti Malaysia, Filipina dan Thailand, pemanfaatan energi terbarukan di Indonesia relatif kecil.

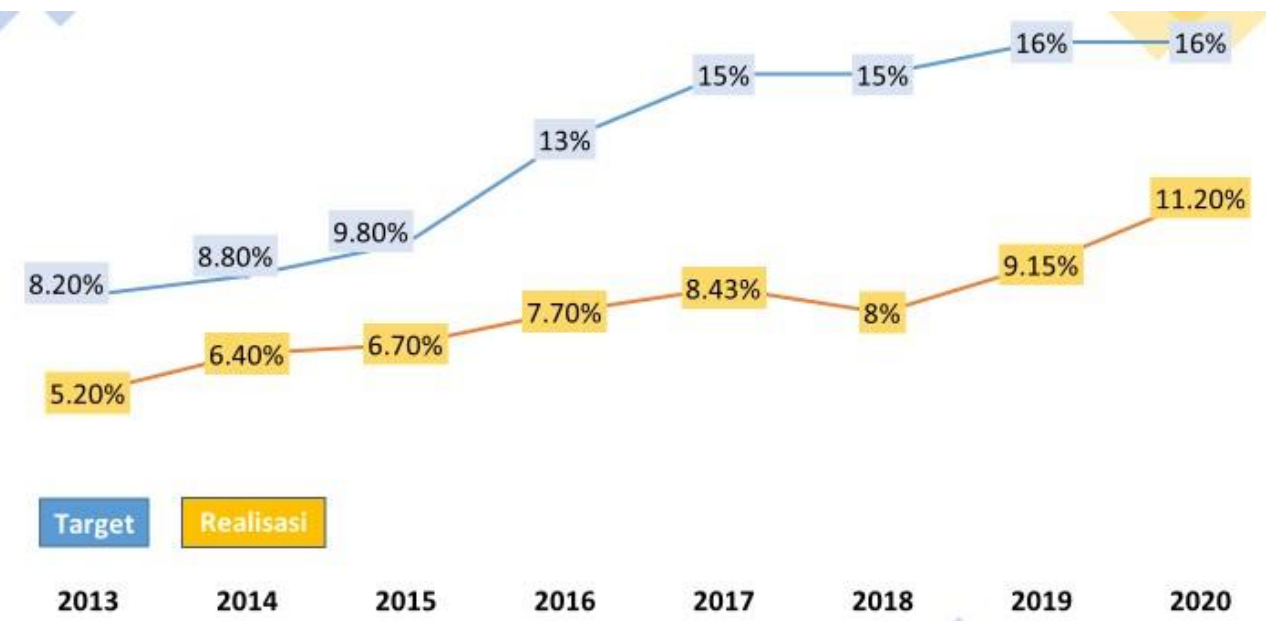

Gambar 6. Perkembangan pangsa energi terbarukan dalam bauran energi Indonesia (Persen)

Sumber: Bappenas 2021

Sebagai ditampakkan pada Gambar 6, pangsa energi terbarukan dalam bauran energi primer nasional pada tahun 2020 adalah sebesar 11,2 persen. Pangsa ini telah meningkat dibandingkan tahun-tahun sebelumnya, namun masih dikhawatirkan tidak dapat mencapai target pangsa energi terbarukan 23 persen pada tahun 2025. Kesenjangan tersebut masih besar, membutuhkan upaya-upaya yang komprehensif dan besar pula untuk mengatasinya.

Peningkatan pangsa energi terbarukan pada tahun 2020 disumbangkan oleh penambahan kapasitas pembangkit listrik dari energi terbarukan, di antaranya PLTA Poso (66 MW) di Sulawesi Tengah, PLTM Sion (12,1 MW) di Sumatera Utara, dan PLTS (13,4 MW) yang tersebar di berbagai wilayah Indonesia. Pada tahun 2020, kapasitas pembangkit listrik energi terbarukan di Indonesia telah mencapai 10.467 MW, yang disumbangkan terutama oleh PLTA, PLTP, dan PLT Bioenergi. Dengan kapasitas tersebut, pangsa energi 
terbarukan dalam power mix (bauran pembangkit tenaga listrik) Indonesia telah mencapai sekitar 14,5 persen.

Sumbangan lainnya adalah dari mandatori penggunaan Bio-diesel. Pada tahun 2020 pemanfaatan Biodiesel mencapai 8,46 juta $\mathrm{kL}$ atau meningkat terus dibandingkan tahuntahun sebelumnya (Gambar 7). Program B30 dimulai pada bulan Januari 2020 dan diharapkan dapat terus meningkatkan pangsa energi terbarukan dalam penggunaan bahan bakar cair di Tanah Air yang selama ini didominasi oleh BBM.

\section{Konsumsi Bio-diesel}

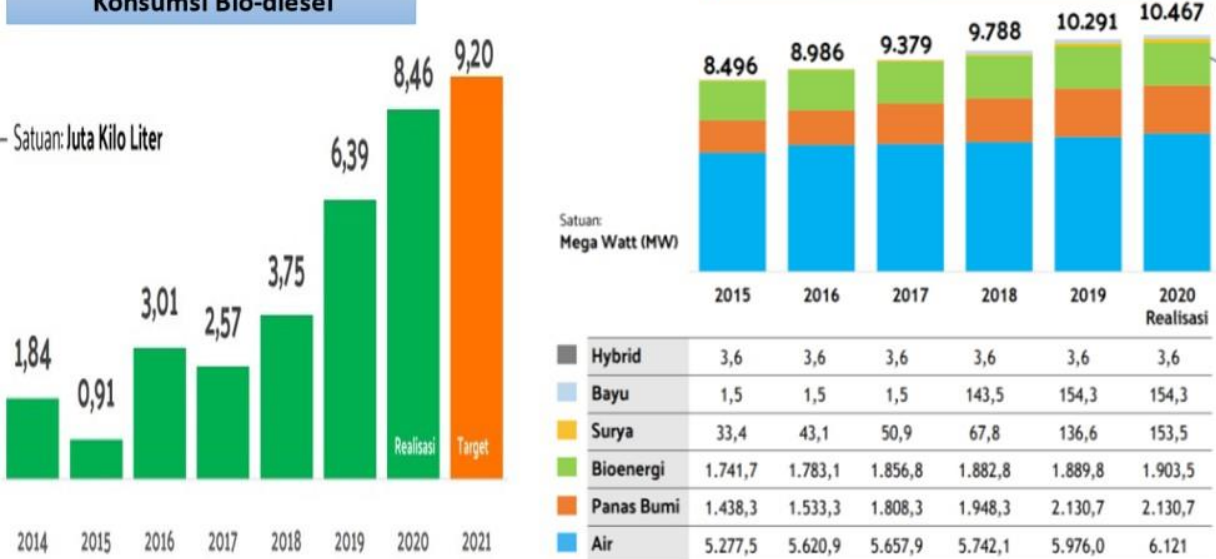

Gambar 7. Perkembangan konsumsi bio-diesel dan kapasitas pembangkit listrik energi terbarukan

Sumber: KESDM 2021

Indonesia adalah pelopor pengembangan minyak kelapa sawit (crude palm oil) menjadi bio-diesel dan yang akan terus dikembangkan untuk menjadi bahan bakar lainnya untuk menggantikan/mengurangi penggunaan BBM. Selain untuk menekan impor minyak mentah dan BBM, upaya pengembangan BBN dari kelapa sawit ini diharapkan menciptakan lapangan kerja yang luas untuk petani Indonesia, di samping menurunkan emisi gas karbon dimana Indonesia juga turut berkomitmen melakukannya.

Penyusunan prioritas merupakan prasyarat yang harus disusun agar roadmap pemulihan tdapat menjadi perbaikan kebjakan dan dapat mendorong penguatan perekonomian nasional. Sebab dibalik krisis yang ada, pandemi Covid-19 ini juga sesungguhnya memberikan peluang ke arah itu. Idealitas tentang perekonomian nasional ke depan seperti misalnya infrastruktur digital yang memadai serta kesadaran akan pentingnya penggunaan energi low carbon berikut perhatian lebih pada lingkungan harus dimasukkan ke dalam roadmap penguatan ini (Ikhsan Modjo, 2020).

Meskipun masih jauh dari tercapai, tahun 2020 menunjukkan arah yang baik upaya meningkatkan pangsa energi terbarukan dalam bauran energi Indonesia ke depan, untuk dalam jangka menengah-memenuhi sasaran 23\% pada tahun 2025.

Pertama, meningkatkan (dengan lebih progresif) kapasitas pembangkitan listrik yang bersumber dari energi terbarukan (panas bumi, biomass, air, dsb.). Dengan semangat serupa, meningkatkan pemanfaatan BBN (bahan bakar nabati) Indonesia dilengkapi dengan pembangunan industri pemrosesannya. Kedua, menjaga agar pertumbuhan konsumsi 
batubara tetap rendah. Upaya mengurangi pemakaian batubara (dengan mengggantikannya dengan sumber-sumber/bahan energi terbarukan) ditingkatkan. Hal serupa diterapkan untuk pemakaian BBM, baik dengan menekan penggunaan mesin-mesin disel untuk pembangkitan listrik, maupun dengan mengembangkan pemakaian biogas dari berbagai macam sumber. Ketiga, memperluas upaya-upaya konservasi energi, yang juga berarti menekan penggunaan bahan bakar fosil.

\section{Daftar Pustaka}

Bappenas. (2021a). Laporan Perkembangan Ekonomi Indonesia dan Dunia: Triwulan IV Tahun 2020, Kedeputian Bidang Ekonomi, Kemeterian Perencanaan Pembangunan Nasional/Bappenas. Jakarta.

Bappenas. (2021b). Studi Pembelajaran Penangan Covid-19, Direktorat Kesehatan dan Gizi Masyarakat, Kementerian Perencanaan Pembangunan Nasional/Bappenas. Jakarta.

Bappenas. (2021c). Proyeksi Covid-19 di Indonesia, Direktorat Kesehatan dan Gizi Masyarakat, Kementerian Perencanaan Pembangunan Nasional/Bappenas. Jakarta.

BPS. (2020). Ekonomi Indonesia 2020 Turun sebesar 2,07 Persen (c-to-c), https://www.bps.go.id/pressrelease/2021/02/05/1811/ekonomi-indonesia-2020turun-sebesar-2-07-persen.

M Ikhsan Modjo. (2020). Memetakan Jalan Penguatan Ekonomi Pasca Pandemi. Jurnal Perencanaan Pembangunan: The Indonesian Journal of Development Planning, 4(2), 103-116. https://doi.org/10.36574/jpp.v4i2.117

Nugroho, H. (2020). Pandemi Covid-19: Tinjau ulang kebijakan mengenai PETI (Pertambangan Tanpa Izin) di Indonesia. Jurnal Perencanaan Pembangunan: The Indonesian Journal of Development Planning, 4(2), 117-125.

Nugroho, H. (2020). Seberapa Desar Dampak Covid-19 Terhadap Industri Pertambangan dan Energi? Analisis Tanggap Cepat dan Usulan Kebijakan untuk Indonesia. Institute Development \& Energy Economics.

Nur Laila Widyastuti, \& Nugroho, H. (2020). Dampak Covid-19 terhadap Industri Minyak dan Gas Bumi: Rekomendasi Kebijakan untuk Indonesia. Jurnal Perencanaan Pembangunan: The Indonesian Journal of Development Planning, 4(2), 166-176. https://doi.org/10.36574/jpp.v4i2.116

Kementerian Energi dan Sumber Daya Mineral. (2021). Capaian Kinerja 2020 dan Program 2021. Kementerian ESDM, Jakarta. 